\title{
Kesiapan Guru dalam Menghadapi Program Full day school
}

\author{
Dina Liana
}

PGMI, STAI Auliaurrasyidin Tembilahan

\begin{abstract}
ABSTRAK
Tujuan penelitian adalah untuk mengetahui kesiapan guru dalam menghadapi program full day school yang akan diterapkan oleh pemerintah. Metode yang digunakan pada penelitian ini adalah jenis penelitian kualitatif karena data-data yang dihasilkan merupakan data deskriptif dengan cara melakukan wawancara. Hasil penelitian yang telah didapatkan oleh peneliti bahwa SMA N 1 Reteh Kabupaten Indragiri Hilir dapat dikatakan siap untuk menerapkan program full day school dengan berbagai persiapan baik dari proses pembelajaran hingga ke sarana dan prasarana sekolah, bahkan sekolah tersebut telah menerapkan program full day school untuk mengembangkan potensi diri siswa dengan berbagai kegiatan-kegiatan yang ada disekolah dengan tujuan menciptakan generasi yang berkompetensi, berkarakter dan mampu bersaing dalam dunia globalisasi sesuai dengan tujuan kurikulum 2013 yaitu membentuk pendidikan karakter.
\end{abstract}

Kata Kunci: kesiapan guru, fullday school

\begin{abstract}
The research is to discover the teacher's readiness on applying full day school program declared by the government. Qualitative research method is used to grow descriptive data in for of interview. The findings clarifies that SMA N 1 Reteh is well-organized in applying full day school program to develop students' potential by serving meaningful activities, in order to create generation of full of competency, attractiveness, and able to compete in the worldwide, as the 2013 curriculum persistence building character education.
\end{abstract}

Keywords: teacher's readiness, fullday school.

Corresponding Author:

Dina Liana

Email address: dinaliana2211@gmail.com

\section{PENDAHULUAN}

Kurikulum 2013 merupakan kurikulum berbasis kompetensi dengan memperkuat proses pembelajaran dan penilaian autentik untuk mencapai kompetensi sikap, pengetahuan, dan keterampilan. Tujuan pengembangan kurikulum 2013 adalah untuk memperbaiki kualitas pendidikan di Indonesia dan menciptakan kualitas penerus bangsa yang bermutu serta mampu membentuk pendidikan karakter bagi generasi penerus yang akan datang. 
Pendidikan karakter merupakan pendidikan yang dapat membentuk pribadi siswa yang lebih mandiri, berpengetahuan tinggi, mempunyai keterampilan yang terasah dan sikap yang baik serta mampu berinterkasi dan bersosialisasi di lingkungan masyarakat, memiliki norma-norma hidup yang baik dan mempunyai nilai luhur terhadap sesama. Sama halnya yang dikemukakan oleh Zainuddin (2015, hal. 132) bahwa pendidikan karakter memerlukan suatu sistem penanaman nilai-nilai karakter yang meliputi komponen-komponen pengetahuan, kesadaran atau kemauan, dan tindakan untuk melaksanakan nilai-nilai luhur baik terhadap diri sendiri maupun orang lain. Pendidikan karakter di sekolah perlu melibatkan semua komponen stakeholders, termasuk komponen pendidikan itu sendiri seperti kurikulum, proses pembelajaran dan penilaian, penanganan atau pengelolaan sekolah, serta etos kerja seluruh lingkungan sekolah. Salah satu kebijakan pemerintah dalam membantu pencapaian pendidikan yang berkarakter saat ini adalah program full day school.

Program full day school merupakan kebijakan baru yang dikeluarkan oleh kemendikbud yang akan diterapkan oleh setiap sekolah sebagai bentuk program dalam mewujudkan tujuan kurikulum 2013 yaitu membentuk pendidikan karakter. namun full day school bukanlah sesuatu yang baru dalam dunia pendidikan, full day school sudah diterapkan di sekolah-sekolah yang berlandaskan agama islam seperti sekolah pesantren ataupun sekolah-sekolah swasta lainnya yang bertujuan untuk pengembangan potensi diri ataupun membentuk karakter siswa.

Full day school adalah sekolah sehari penuh, yang artinya siswa akan berada disekolah dari pagi hingga sore hari. Penerapan full day school akan membantu siswa untuk lebih mandiri, mengembangkan kemampuan intelektual, membantu siswa dalam mengasah keterampilan sehingga siswa memiliki keahlian untuk bersaing dalam dunia kerja dan mampu membantu siswa dalam membangun potensi yang ada dalam dirinya.

Penerapan full day school merupakan sebuah upaya program pembelajaran yang menekankan siswa untuk lebih banyak bearada di sekolah dengan segala aktivitas yang ada dan menekankan terhadap berbagai kegiatan edukasi sehingga siswa akan lebih banyak mengeksplor dirinya. Penerapan full day school bukan berarti siswa belajar materi dari pagi hingga sore namun siswa hanya belajar materi setengah hari saja selanjutnya siswa akan dibimbing untuk pengembangan potensi diri agar dapat memperkuat karakter siswa dalam bentuk kegiatan ekstrakurikuler sebagai bentuk tujuan dari program full day school.

Selain tujuan ada beberapa komponen yag harus diperhatikan dalam menerapkan full day school yaitu 1. Komitmen harus ditegakkan secara konsisten, 2. Pengelola harus tegas dan juga menerapkan sanksi yang konsisten, dan 3. Sarana dan prasarana harus mendukung agar dapat menunjang ketercapaian tujuan full day school yaitu membentuk karakter siswa baik dari sisi pengetahuan, sikap dan keterampilan.

Program full day school yang akan diterapkan oleh pemerintah mempunyai tujuan dan harapan yang sangat besar untuk dunia pendidikan terutama bagi 
pendidik ataupun guru, guru diharapkan mampu mengimplementasikan dan mempunyai komitmen untuk mampu membentuk karakter siswa ataupun membantu siswa menguasai berbagai kompetensi yang diharapkan. Guru harus mampu menginovasi siswa agar mampu mengembangkan sikap dan potensinya

Berdasarkan uraian diatas penulis telah melakukan penelitian dengan judul Kesiapan Guru dalam Menghadapi Program Full day school di Kabupaten Indragiri Hilir.

\section{Full day school}

Menurut etimologi, kata full day school berasal dari Bahasa Inggris. Terdiri dari kata full mengandung arti penuh, dan day artinya hari. Maka full day mengandung arti sehari penuh. Full day juga berarti hari sibuk. Sedangkan School artinya Sekolah. Jadi, arti dari Full day school jika dilihat dari segi etimologinya berarti kegiatan belajar yang dilakukan sehari penuh disekolah (Islami A, 2016, hal. 8). Sama halnya yang dikemukakan oleh Salim (1988, hal. 340) bahwa full day school berasal dari bahasa inggris, full artinya penuh, dayartinya hari, sedangkan school artinya sekolah. Full day school berarti sekolah sepanjang hari.

Menurut terminologi atau arti secara luas, Full day school mengandung arti system pendidikan yang menerapkan pembelajaran atau kegiatan belajar mengajar sehari penuh dengan memadukan system pengajaran yang intensif yakni dengan menambah jam pelajaran untuk pendalaman materi pelajaran serta pengembangan diri dan kreatifitas. Pelaksanaan pembelajaran yang dilaksanakan di sekolah mulai pagi hingga sore hari, secara rutin sesuai dengan program pada tiap jenjang pendidikannya. Dalam Full day school, lembaga bebas mengatur jadwal mata pelajaran sendiri dengan tetap mengacu pada standar nasional alokasi waktu sebagai standar minimal dan sesuai bobot mata pelajaran, ditambah dengan model-model pendalamannya. Jadi yang terpenting dalam Full day school adalah pengaturan jadwal mata pelajaran (Islami A, 2016, hal. 8).

Sistem full day school pada dasarnya adalah integrated curriculum dan integrated activity yang merupakan bentuk pembelajaran yang diharapkan dapat membentuk siswa yang berintelektual tinggi yang dapat memadukan aspek ketrampilan dan pengetahuan dengan sikap yang baik (Setiayarini, Joyoatmojo, \& Sunardi, 2014, hal. 238). Full day school merupakan salah satu program pembelajaran dengan menekankan siswa agar lebih lama berada di sekolah bukan hanya sekedar karena adanya tambahan pelajaran atau sekedar kegiatan ekstrakulikuler. Namun, dengan adanya program ini lebih menekankan dalam pembentukan karakter peserta didik dengan pemberian-pemberian atau penanaman nilai-nilai moral (Islami A, 2016, hal. 9).

Pelaksanaan full day school merupakan alternatif dari revolusi pendidikan terhadap masalalah-masalah yang ada dan terjadi pada siswa. Sebagai solusi alternative pelaksanaan full day school ditunjang dengan berbagai alasan yang patut dipertimbangkan dalam pendidikan siswa. Seperti yang dikemukakan oleh Clark dalam Setiyarini, Joyoatmojo \& Sunardi (2014, hal. 238) yaitu dalam pertumbuhannya 
program sehari penuh diakibatkan oleh beberapa faktor, di dalamnya banyak orang tua tunggal dan orang tua yang keduanya bekerja yang membutuhkan program sehari penuh untuk anak mereka, di samping ada sebagian yang percaya bahwa program sehari penuh merupakan program sekolah yang dapat mempersiapkan siswa menjadi lebih baik.

Dalam pelaksanaan full day school, sekolah harus menyesuaian programprogram akademik seperti: pengaturan jadwal mata pelajaran, strategi pembelajaran, sarana dan prasarana yang memadai serta pendalaman materi adalah yang paling utama agar tujuan full day school dapat tercapai dengan baik (Setiayarini, Joyoatmojo, \& Sunardi, 2014, hal. 242).

Adanya full day school siswa akan lebih banyak belajar dari pada bermain, karena adanya waktu yang lama dalam kelas, hal ini mengakibatkan produktifitas siswa yang tinggi, selain itu siswa akan dekat dengan guru, siswa juga menunjukkan sikap yang lebih positif, karena tidak ada waktu luang untuk melakukan penyimpangan-penyimpangan karena seharian siswa berada di kelas dan berada dalam pengawasan guru sehingga siswa akan memperoleh banyak keuntungan secara akademik dan social (Ma'ruf, 2015, hal. 6).

Menurut Sehudin dalam Setiyarini, Joyoatmojo \& Sunardi (2014, hal. 238) mengatakan bahwa garis-garis besar program full day school adalah sebagai berikut:

1. Dapat membentuk sikap siswa

a) Pembentukan sikap islami yang terdiri atas pengetahuan dasar tentang Iman dan pengetahuan umum, pengetahuan dasar tentang akhlak terpuji dan tercela, kecintaan kepada Allah dan Rosulnya, jujur dan bertanggung jawab.

b) Pembiasaan berbudaya Islam terdiri atas gemar beribadah, gemar belajar, disiplin, kreatif, man`diri, hidup bersih dan sehat.

2. Penguasaan pengetahuan dan ketrampilan seperti pengetahuan materi-materi pokok program pendidikan, mengetahui dan terampil dalam beribadah seharihari, mengetahui dan terampil membaca dan menulis.

Sistem pembelajaran full day school adalah keterkaitan antara unsur-unsur dalam pembelajaran seperti lingkungan tempat belajar, metode, strategi, teknologi, dan media agar terjadi tindak belajar yang menekankan pada pembelajaran aktif (active learning), kreatif (creative learning), efektif (effective learning), dan menyenangkan (fun learning) dalam mencapai tujuan yang ditentukan. Selain itu pembelajaran tersebut juga dilaksanakan secara penuh (full day school), aktifitas siswa lebih banyak dilakukan di sekolah dari pada di rumah. Meskipun begitu, proses pembelajaran yang lebih lama di sekolah tidak hanya berlangsung di dalam kelas, karena konsep awal dibentuknya sistem full day school ini bukan menambah materi ajar dan jam pelajaran yang sudah ditetapkan oleh Depdiknas seperti yang ada dalam kurikulum 2013 tersebut, melainkan tambahan jam sekolah digunakan untuk pengayaan materi ajar yang disampaikan dengan metode pembelajaran yang kreatif dan menyenangkan untuk menambah wawasan dan memperdalam ilmu 
pengetahuan, menyelesaikan tugas dengan bimbingan guru, pembinaan mental, jiwa dan moral anak (Setiayarini, Joyoatmojo, \& Sunardi, 2014, hal. 239).

Full day school merupakan sebuah terobosan baru pemerintah yang dilakukan secara sadar untuk mengatur adanya tindak belajar yang direncanakan, dilaksanakan, dan dievaluasi. Untuk mendukung ketercapaian tujuan full day school diperlukan guru yang kereatif agar siswa tidak merasa takut dan bosan selama berada di sekolah seharian. Guru harus dapat mengembangkan kegiatan yang menarik dan beragam, membuat alat bantu belajar, memanfaatkan lingkungan, mengelola kelas dan sumber belajar untuk mencapai hasil belajar yang diinginkan. Selain itu guru juga harus mengembangkan suatu proses pembelajaran yang efektif, yaitu pembelajaran yang dilakukan untuk mencapai tujuan pembelajaran yaitu tercapainya kompetensi siswa (Setiayarini, Joyoatmojo, \& Sunardi, 2014, hal. 240).

\section{Keunggulan dan Kelemahan Sistem Full day School}

Menurut Hasan (2006, hal. 114) full day school sebagai sebuah konsep yang inovatif yang lahir dari keprihatinan sistem persekolahan konvensional, mempunyai sisi-sisi keunggulan antara lain sebagai berikut:

1. Sistem full day school lebih memungkinkan terwujudnya pendidikan utuh. Benyamin S. Bloon dalam Hasan (2006, hal. 114)menyatakan bahwa sasaran (objectives) pendidikan meliputi tiga bidang yakni kognitif, afektif, dan psikomotorik. Pada lembaga pendidikan konvensional, sering dikecewakan karena hanya mampu membentuk segi kognitif, namun sangat lemah bahkan nihil pada segi afektif dan psikomotoriknya (Azizy dalam Hasan (2006, hal. 114)). Melalui sistem asrama dan pola full day school, tendensi kearah penguatan pada sisi kognitif saja dapat lebih dihindarkan, dalam arti aspek afektif siswa dapat lebih diarahkan. Demikian juga aspek psikomotoriknya. Dalam konteks demikian inilah sistem pendidikan yang selama ini diterapkan di pesantren sehingga menemukan titik signifikansinya.

2. Sistem fullday school lebih memungkinkan terwujudnya intensifikasi dan efektivitas proses edukasi. Full day school dengan pola asrama yang tersentralisir dan sistem pengawasan 24 jam sangat memungkinkan bagi terwujudnya intensifikasi proses pendidikan dalam arti siswa lebih mudah diarahkan dan dibentuk sesuai dengan misi dan orientasi lembaga bersangkutan, sebab aktivitas siswa lebih mudah terpantau karena sejak awal sudah diarahkan.

3. Sistem full day school merupakan lembaga yang terbukti efektif dalam mengaplikasikan kemampuan berbahasa asing, seperti dibuktikan di sejumlah lembaga semisal pesantren Gontor Ponorogo, al-Amin Sumenep, dan lembaga kursus bahasa asing di Pare Kediri yang telah menerapkan sistem full day school.

Namun demikian, sistem pembelajaran model fullday school tidak terlepas dari kelemahan dan kekurangan menurut Hasan (2006, hal. 115), misalnya: 
1. Sistem fullday school acapkali menimbulkan rasa bosan pada siswa. Sistem pembelajaran dengan pola fullday school membutuhkan kesiapan baik fisik, psikologis, maupun intelektual yang bagus. Jadwal kegiatan pembelajaran yang padat dan penerapan sanksi yang konsisten, dalam batas tertentu akan menyebabkan siswa menjadi jenuh. Namun demikian, bagi mereka yang telah siap, hal tersebut bukan suatu masalah, tetapi justru akan mendatangkan keasyikan tersendiri. Oleh karenanya, kejelian dan improvisasi pengelola dalam hal ini sangatlah dibutuhkan. Keahlian dalam merancang fullday school sehingga tidak membosankan bahkan mengasyikka sangatlah penting. Demikian juga kerjasama dengan semua pihak, yakni pakar pendidikan, psikolog, dan expertexpert lainnya sangat perlu digalakkan.

2. Sistem full day school memerlukan perhatian dan kesungguhan manajemen bagi pengelola. Agar proses pembelajaran pada lembaga pendidikan yang berpola full day school berlangsung optimal, sangat dibutuhkan perhatian dan curahan pemikiran terlebih dari pengelolanya, bahkan pengorbanan baik fisik, psikologis, material, dan lainnya. Mengelola full day school apalagi dengan misi memperkuat ilmu jelas sangat membutuhkan kerapian manajerial dan ketajaman sekaligus kepekaan konseptual, yakni bagaimana agar pada satu sisi terdidik merasa enak belajar, berdisiplin, dan merasa at home di tengah ketegasan dan keketatan sanksi dan kepadatan proses edukasi. Tanpa hal demikian, full day school tidak akan mencapai hasil optimal bahkan boleh jadi hanya sekedar rutinitas yang tanpa makna.

\section{METODE PENELITIAN}

Penelitian ini dilaksanakan di SMA N 1 Reteh Kabupaten Indragirihilir Provinsi Riau. Jenis penelitian yang dilakukan adalah penelitian kualitatif karena data-data yang dihasilkan merupakan data deskriptif dengan cara melakukan wawancara. Menurut Lufri (2010, hal. 56) penelitian deskriptif ini bertujuan untuk memecahkan masalah aktual yang dihadapi serta mengumpulkan data atau informasi untuk disusun, dijelaskan dan dianalisis. Selanjutnya menurut Moleong (2003, hal. 6) penelitian kualitatif adalah penelitian yang bermaksud untuk memahami fenomena tentang apa yang dialami oleh subjek penelitian secara holistik (utuh) dan dengan cara deskripsi dalam bentuk kata-kata dan bahasa pada suatu konteks khusus yang alamiah.

\section{HASIL DAN PEMBAHASAN}

\section{Kesiapan Guru dalam Menghadapi Program Full day school}

Dari hasil penelitian dengan cara wawancara terhadap guru peneliti telah mendapatkan hasil mengenai kesiapan guru dalam menghadapi program full day school, dapat diketahui bahwa guru dari masing-masing sekolah telah siap untuk 
menerapkan full day school bahkan dari beberapa sekolah telah melaksanakan program full day school jauh sebelum pemerintah merencanakan program tersebut.

Dalam hal ini guru merupakan garda terdepan dalam mencetak generasi yang aktif, kreatif dan inovasi, sehingga peran guru sangatlah penting dalam menata, membimbing dan mengarahkan siswa untuk mencapai suatu keberhasilan dalam proses belajar siswa. Sama halnya yang dikemukakan oleh Qomariyah (2014, hal. 24) guru merupakan faktor yang sangat besar keberadaannya dan guru juga mempunyai andil besar yaitu mencetak generasi yang aktif, kreatif, dan inovatif sesuai pendidikan nasional dalam pengaruhnya terhadap keberhasilan peserta didik dalam proses belajar mengajar.

Adapun usaha guru yang dilakukan untuk menghadapi program full day school adalah:

a. Team Teaching, dimana guru membentuk sebuah tim untuk memperbaiki cara pembelajaran, menerapkan strategi, pendekatan, metode, teknik dan model pembelajaran yang dapat membuat siswa lebih tertarik untuk belajar dan termotivasi dalam belajar serta merencakan sebuah pembelajaran yang menyenangkan sehingga siswa tidak merasa bosan berada di sekolah selama seharian.

b. Guru mengikuti pelatihan ataupun workshop dan kegiatan lainnya yang bersifat perbaikan tentang pembelajaran untuk sebuah ketercapaian tujuan program full day school.

c. Guru akan lebih meluangkan waktu untuk membimbing dalam pengembangan potensi diri siswa

Tujuan dari usaha para guru tersebut agar dapat menyetarakan kemampuan yang dimiliki guru dalam proses pembelajaran, selain itu agar program full day school dapat berjalan sesuai rencana pemerintah untuk mencapai tujuan dan menghasilkan pendidikan yang berkarakter.

Berikut merupakan data wawancara yang telah dipaparkan oleh guru dari masing-masing sekolah mengenai kesiapan dalam menghadapi program full day school.

a. Kesiapan Guru SMA N 1 Reteh

Saya mengetahui bahwa pemerintah akan menerapkan program full day school. Saya siap menerapkan full day school, karna pada dasarnya disekolah ini memang sudah menerapkan program tersebut, setelah materi selesai siswa akan melanjutkan kegiatan pengembangan potensi diri di sekolah hingga sore hari, kegiatan-kegiatan tersebut seperti mengikuti marching band, pramuka, seni tari dll. (Wawancara dengan R, 4-1-2017)

b. Kesiapan Guru SMA N 1 Reteh

Saya mengetahui bahwa pemerintah akan menerapkan program full day school melalui berita. Kami sebagai guru siap dalam hal apapaun yang direncakan oleh pemerintah apalagi berkaitan dengan pendidikan karna hal tersebut memang 
sudah menjadi tugas kami. Persiapan yang harus kami lakukan adalah membuat RPP sehingga pembelajaran dalam kelas lebih menyenangkan dan dapat meningkatkan motivasi belajar siswa dan siswa tidak merasa bosan berada di sekolah seharian (Wawancara dengan L, 3-1-2017).

c. Keisapan Guru SMA N 1 Reteh

Saya mengetahui dari berita mengenai wacana program full day school tersebut. Seandainya dikatakan siap, kami sebagai guru siap menerapkan program full day school tersebut. Karna di sekolah ini sebenarnya memang sudah diterapkan full day school. Setelah materi selesai siswa akan mengikuti kegiatan pengembangan potensi diri yang ada disekolah ini, seperti, organisasi osis, pramuka, marching band, seni tari, bahkah sarana prasarana seperti laboratorium disekolah ini sudah sangat memadai (Wawacara WM, 3-1-2017).

d. Kesiapan Guru SMA N 1 Reteh

Saya mengetahui melalui berita mengenai akan dilaksanakannya program full day tersebut. Saya sebagai guru siap untuk menerapkan program tersebut, namun untuk siswa mungkin harus dijelaskan kembali mengenai program ini karna siswa disekolah ini hanya sebagian kecil saja yang mengikuti kegiatan-kegiatan yang ada di sekolah ini (Wawancara S, 4-1-2017).

e. Kesiapan Guru SMA N 1 Reteh

Saya mengetahui melalui berita tentang full day school, sebagai guru siap tidak siap harus dilaksnakan jika itu sudah diterapkan oleh pemerintah. Pesrisapan yang akan saya lakukan adalah mengikuti pelatihan-pelatihan untuk memperbaiki cara mengajar yang bertujuan agar pembelajaran lebih menyenangkan dan siswa tidak merasa bosan selama seharian di sekolah (Wawancara dengan I, 4-1-2017)

Dari hasil data wawancara tersebut dapat disimpulkan bahwa guru di SMA N 1 Reteh Kabupaten Indragirihilir telah siap menerapkan program full day school.

Faktor Pendukung dan Penghambat dalam Menghadapi Program Full day school

Adapun faktor pendukung dan penghambat yang peneliti dapatkan dari data hasil wawancara dengan guru SMA N 1 Reteh Kabupaten Indragiri Hilir akan dijabarkan oleh peneliti sebagai berikut.

\section{a. Faktor pendukung}

Faktor pendukung dari hasil wawancara dengan guru adalah a). Guru mempunyai motivasi untuk mengikuti pelatihan-pelatihan ataupun workshop mengenai peningkatan pembelajaran disekolah, b). Guru siap melaksanakan hal apapun yang telah direncakan pemerintah yang mempunyai tujuan untuk meningkatkan kualitas pendidikan dan c). Guru siap bekerja sama untuk mengembangkan potensi diri ataupun karakter siswa.

\section{b. Faktor penghambat}

Factor yang menjadi penghambat dalam menghadapi program full day school dari data hasil wawancara dengan guru adalah a). sebagian guru masih terkendala mengenai proses pembelajaran yang dapat meningkatkan motivasi belajar siswa 
karna sebagian guru masih menggunakan metode ceramah dalam proses belajar b). motivasi siswa masih harus ditingkatkan lagi agar mereka mempunyai minat untuk mengikuti kegiatan-kegiatan yang ada disekolah.

\section{Peranan Sekolah dalam Upaya Melaksanakan Program Full day school}

Peranan sekolah dalam mendukung upaya melaksanakan program full day school dapat dikemukakan sebagai berikut.

\section{a. Kepala Sekolah harus memberikan arahan terhadap para guru yang bersifat} interen dan eksteren.

Kepala sekolah harus memberikan pengarahan kepada guru yang bersifat interen seperti menyampaikan informasi tentang pelaksanaan program full day school, sedangkan yang bersifat eksteren sekolah harus menugaskan guru-guru untuk mengikuti pelatihan-pelatihan ataupun workshop Dinas Pendidikan dan Kebudayaan yang berkaitan mengenai program full day school.

b. Pengadaan sarana dan prasarana agar dapat menunjang kegiatan-kegiatan yang sifatnya dapat mengembangkan potensi diri siswa

Sekolah harus menyediakan sarana dan prasarana sekolah agar siswa dapat mengikuti kegiatan-kegiatan yang dapat mengembangkan potensi diri siswa ataupun kegiatan-kegiatan yang dapat membangun karakter diri siswa seperti.

1) Membangun laboratorium jika sekolah tersebut belum terdapat labor.

2) Melengkapi alat-alat peraga.

3) Menambah fasilitas elektronik seperti: LCD proyektor agar dapat mempermudah proses belajar mengajar.

4) Menyediakan hotspot area agar dapat mempermudah siswa untuk mendapatkan informasi.

c. Melaksankan supervisi guna untuk meningkatkan kualitas proses belajar mengajar guru

Supervisi yang dilakukan sekolah merupakan hal yang paling penting dalam perbaikan proses pembelajaran. Dengan demikian sekolah dapat memonitoring para guru, sehingga sekolah dapat mengetahui mana guru yang sudah kreatif dan inovatif dalam proses pembelajaran karena program full day school diharapkan guru yang kreatif agar mampu membangun potensi diri ataupun karakter siswa. Guru yang masih cendrung dalam pembelajaran konvensional dapat diberikan masukan atau pengetahuan mengenai keretifitas guru dalam pembelajaran agar dapat menciptakan proses pembelajaran yang menyenangkan dan dapat meningkatkan motivasi belajar siswa. Supervisi bertujuan agar guru dapat mengetahui dimana sisi kekurangannya dalam proses pembelajaran.

Dari hasil supervisi masih banyak hal yang harus dibenahi dalam permasalahan-permasalah yang dihadapi guru dalam menunjang pelaksanaan program full day school masih. Pemasalahan tersebut antara lain: 
1) Guru kurang terampil dalam menggunakan metode pembelajaran yang menarik minat belajar siswa.

2) Kuranganya kompetensi guru dalam pembelajaran.

3) Keterbatasan dana anggaran yang digunakan dalam menambah dan menunjang sarana dan prasarana sehingga guru mengalami keterbatasan dalam proses pembelajaran.

\section{SIMPULAN}

Berdasarkan hasil analisis dan pembahasan penelitian, maka dapat disimpulkan bahwa kesiapan guru-guru SMA N 1 Reteh Kabupaten Indragiri Hilir dalam menghadapi full day school dapat dikatakan telah siap untuk menerapkan program full day school, bahkan sekolah SMA N 1 Reteh Kabupaten Indragiri Hilir telah menerapkan program full day school tersebut. Kesiapan ini akan lebih mempermudah pemerintah dalam pelaksanaan program full day school sehingga tujuan kurikulum 2013 dapat tercapai yaitu menciptakan generasi yang berkompetensi, berkarakter dan mampu bersaing dalam dunia globalisasi.

\section{DAFTAR PUSTAKA}

Hasan, N. (2006). Full Day School (Model Alternatif Pembelajaran Bahasa Asing). Jurnal Tadris, 1(1), 114-115.

Islami A, M. N. (2016). Implementasi Program Pendidikan Full Day School di MI Muhammadiyah Karanglo Kecamatan Cilongko Kabupaten Banyumas. IAIN Purwokerto. Banyumas: IAIN Purwokerto.

Lufri. (2010). Strategi Pembelajaran Biologi. Padang: UNP Press.

Ma'ruf, A. (2015). Implementasi Full Day School dalam Membentuk Akhlaq Siswa di SMP Ta'mirul Islam Surakarta Tahun Pelajaran 2015/ 2016. Surakarta: Universitas Muhammadiyah Surakarta.

Moleong, L. J. (2003). Metodologi Penelitian Kualitatif. Jakarta: PT. Raja Grafindo Persada.

Qomariyah. (2014). Kesiapan Guru dalam Menghadapi Implementasi Kurikulum 2013. Jurnal Pendidikan Ekonomi IKIP Veteran Semarang, 2(1), 24.

Setiayarini, I., Joyoatmojo, \& Sunardi. (2014). Penerapan Sistem Pemebelajaran "Fun \& Full Day School" untuk Meningkakan Religiusitas Peserta Didikdi SDIT Al Islam Kudus. Jurnal Teknologi Pendidikan, 238-242.

Zainuddin, H. M. (2015). Implemetasi Kurikulum 2013 dalam Membentuk Karakter Anak Bangsa. Jurnal Universum, 9(1), 132. 